\title{
The Association between Economic Value Added, Market Value Added and Leverage
}

\author{
Aloy Niresh, J. ${ }^{1} \&$ Alfred, M. ${ }^{2}$ \\ ${ }^{1}$ Department of Finance and Accountancy, Vavuniya Campus of the University of Jaffna, Sri Lanka \\ ${ }^{2}$ Department of Management Studies, University of Peradeniya, Sri Lanka \\ Correspondence: Aloy Niresh, J., Department of Finance and Accountancy, Vavuniya Campus of the University \\ of Jaffna, Sri Lanka. E-mail: aloy157@gmail.com
}

Received: June 17, 2014

Accepted: August 1, 2014

Online Published: September 25, 2014

doi:10.5539/ijbm.v9n10p126

URL: http://dx.doi.org/10.5539/ijbm.v9n10p126

\begin{abstract}
It is commonly agreed in notion that the financial aim of the firm should be the magnification of shareholder value as exposed in the market value of the firms' stocks. Shareholder value creation generally be represented by the Market Value Added (MVA). The best way to maximize MVA is to maximize Economic Value Added (EVA), which reflects the net earnings of the organization in surplus of the charges for shareholders' endowed capital. In this research leverage and EVA have been used as the independent variables whereas MVA has been used as the measure of shareholder wealth creation. Correlation and regression methods have been employed to find out in what way financial managers can practice the effects of leverage and EVA to maximize MVA. There is no indicative association between EVA and MVA and leverage and MVA, the findings reveal. Furthermore, the results showed that both EVA as well as leverage have no profound impact on Market Value Added of the selected listed private banks in Sri Lanka.
\end{abstract}

Keywords: economic value added, leverage, market value added

\section{Introduction}

Shareholders' wealth maximization should be the ultimate goal of most of the organizations. It is tentatively rational and operationally viable normative objective for managing the financial decision making. EVA is now a day widely adopted as a performance metric by researchers all over the world where as the usage of Return on Equity, Net profit and Return on Assets known as traditional performance metrics became obsolete now a days.

The idea of stockholder value formation is an elementary principle of efficacious financial management. Shareholder value creation can be attained through maximizing the market value of investors' wealth. Establishing the market value involves the procedure of valuation. Determining value and value drivers is crucial to evaluate an investment regarding whether it is sound or not. In this analysis the leverage effect on MVA and the effect of EVA on MVA is investigated. Total leverage can be derived by multiplying financial leverage by operational leverage. It would be possible to forecast what impact the leverage will have on MVA as soon as the total leverage is determined. The verdicts of this study could be valuable not only to financial managers but also to the managers those who are at all levels in a business organization. Furthermore, potential and existing shareholders can get to know the worth of their investments made in the organization.

\subsection{Objectives of the Study}

The objectives are directed towards following;

* To identify the association between leverage, EVA and MVA;

* To discover the effects of leverage and EVA on MVA.

\subsection{Hypotheses of the Study}

Following hypotheses were formulated for the study.

$\mathrm{H}_{1}$ :- There is a significant relationship between EVA and MVA;

$\mathrm{H}_{2}$ :- Total leverage exhibits a significant relationship with MVA;

$\mathrm{H}_{3}$ :- There is a significant impact of EVA on MVA; 
$\mathrm{H}_{4}$ :- Total leverage is having a profound impact on MVA.

\section{The Concepts of EVA, MVA and Leverage}

\subsection{EVA and MVA}

Modern financial management emphasizes that a firm must seek to maximize shareholder value. Shareholder wealth creation normally be represented by the market value of the firms' shares. It is the shareholders' appraisal of the firms' efficiency in employing their capital. The capital contributed by shareholders is reflected by the book value of the firms' shares. Market Value Added also known as shareholder value creation is the excess of market value over book value.

$$
\text { MVA = Market Value - Capital Employed }
$$

Market value as stated in the equation mentioned above is the total of the firms' market value of debt and market value of equity. Invested capital also known as capital employed is the summation of equity and debt capital supplied by the firms' shareholders and debt holders to finance assets. Positive MVA is the sign of shareholder value creation. Managers must aim at earning higher MVA for shareholders and it can be attained only when the firm earns a return in excess of the cost of capital. MVA would be reduced if the firm invests capital in projects which are having negative NPV.

Market Value Added is considered as the best indicator of shareholders' wealth creation from an investor's point of view. MVA presents a coherent image that growth for its own sake does not generate value. Value can only be created when the growth stratagem paves way to additional value that surpass the additional capital provided. The value will be demolished if the net present value of the strategy is negative. It emphasizes that only if managers invest in projects which have positive net present values, value will be created.

Economic Value Added also known as economic profit is explained as net earnings (profit after tax) in surplus of the charges for capital employed.

Economic Value Added = Net Operating Profit after Tax (NOPAT) - Charges for Capital Employed

Profit after depreciation and taxes denoted by NOPAT is calculated by disregarding interest on debt. In other words NOPAT is Profit before Interest and Taxes (PBIT) minus tax without any adjustments for interest. It can also be calculated as Profit after Tax (PAT) plus after tax interest.

$$
\text { NOPAT }=\text { PBIT }(1-T)
$$

EVA is an assessment of an annual profit of a firm and it differs substantially from accounting profit. It exemplifies the residual income remaining after all opportunity cost of capital is covered. The change between the return on a company's capital and the cost of capital employed is measured by EVA. Negative EVA signifies value demolition whereas value creation is represented by positive EVA.

MVA is the present value of the firm's expected future EVAs. Thus, the connectivity between EVA and MVA is justified.

$$
\mathrm{MVA}=\text { Present value of all future EVA }
$$

\section{Example}

At the commencement of the year the company named "X" employed capital worth of LKR 10 million, which consists of $70 \%$ equity and $30 \%$ debt. The interest charged on debt is $15 \%$ before tax. The tax rate is $20 \%$ and the Weighted Average Cost of Capital (WACC) is $18 \%$. The profit before the deduction of interest and tax is LKR 6 million.

The return on invested capital after tax is $6 \mathrm{~m} / 10 \mathrm{~m} \times(1-$ tax rate of $20 \%)=48 \%$.

$$
\begin{aligned}
\text { EVA } & =(\text { Return on Invested Capital }- \text { WACC }) \times \text { Capital Employed } \\
& =(48 \%-18 \%) \times 10 \mathrm{~m} \\
& =30 \% \times \text { LKR } 10 \text { million } \\
& =\text { LKR } 3 \text { million }
\end{aligned}
$$

If the future EVAs are anticipated to remain for an indefinite period at LKR 3 million per annum then the calculation of MVA will be in the following manner:

$$
\begin{aligned}
& \mathrm{MVA}=\mathrm{EVA} / \mathrm{WACC} \\
& =\mathrm{LKR} 3 \text { million } / 18 \%
\end{aligned}
$$


$=$ LKR 16.7 million

MVA of a firm can be maximized via the following ways (Stewart 1991:137; Ernst \& Young 1994:10; Firer 1995:57; Davidson 2003:49).

- By eliminating projects that have a negative EVA;

- By making new investments in projects that have positive EVA;

- By broadening existing projects with of positive EVA.

As compared to other accounting measures, EVA is the better prognosticator of market value, several studies emphasize. According to Misra and Kanwal (2007), EVA is the key determinant of MVA as it better reveals the variations in share value than the traditional accounting measures. All the future EVAs which will be generated by a company is represented by MVA. Hence an organization can maximize its MVA by maximizing EVA.

\subsection{Degree of Operational Leverage, Financial Leverage and Total Leverage}

The percentage change in the earnings before interest and taxes relative to a given percentage change in sales is defined as Operational Leverage.

Degree of Operating Leverage $(\mathrm{DOL})=\%$ change in EBIT $\%$ change in sales.

The equation can also be written as follows:

$$
\mathrm{DOL}=\text { Contribution/EBIT }
$$

If the fixed costs are 0 , then the resulting figure will be equal to one. In such a situation contribution and Earnings before Interest and Tax (EBIT) both will be equal. A DOL factor of 1.2 implies that the operating profit will change by $12 \%$ for every $10 \%$ change in sales (all other things being equal).

The percentage change in Earnings per Share (EPS) due to a given percentage change in EBIT is known as Financial Leverage.

Degree of Financial Leverage $(\mathrm{DFL})=\%$ change in EPS $/ \%$ change in EBIT

The following equation can also be used to calculate DFL:

$$
\mathrm{DFL}=\mathrm{EBIT} / \mathrm{PBT}
$$

The ability of a business to use fixed financial charges to magnify the effects of changes in EBIT on the EPS and profits is referred to as financial leverage. It involves the use of funds obtained at a fixed cost with a view to increase the earnings available to the shareholders in future. A DFL factor of 2.3 implies that the EBIT will change by $23 \%$ for every $10 \%$ change in Profit before Tax (all other things being equal).

Total leverage can be calculated as follows;

$$
\text { Degree of Total Leverage }(\mathrm{DTL})=\text { DOL } x \text { DFL }
$$

Or

$$
\mathrm{DTL}=\% \text { change in } \mathrm{EPS} / \% \text { change in sales }
$$

Wide fluctuations in EPS for a given change in sales are caused by operating and financial leverage together. As it can be seen from the equation that the total leverage is the outcome of the multiplication of operating leverage and financial leverage. A total leverage of $1.2 \times 2.3=2.76$ indicates that the profit before tax will change by $27.6 \%$ for every $10 \%$ change in sales.

\subsection{Link between EVA, Leverage and MVA}

Theoretically MVA is identical or equal to the present value of all future EVAs. MVA can be calculated as a perpetuity based on the assumption that the expected future growth in EVA will be at a constant rate.

\section{Example}

Company D has a current EVA of LKR 180 million. Its Weighted Average Cost of Capital (WACC) is $18 \%$. The theoretical MVA can be calculated as follows if no future growth in EVA is expected:

$$
\begin{aligned}
\text { MVA } & =\text { Present value of future EVAs } \\
& =\text { Current EVA/WACC } \\
& =\text { LKR } 180 \mathrm{mn} / 0.18 \\
& =\text { LKR } 1,000 \text { million }
\end{aligned}
$$


In this case, MVA is 5.5 times of the current EVA (LKR 1,000mn/LKR $180 \mathrm{mn}$ ).

If EVA is anticipated to grow at a constant rate of $12 \%$ in future, MVA can be theoretically calculated as follows:

$$
\begin{gathered}
\text { MVA }=\text { PV }(\text { Future EVA }) \\
=\text { Current EVA } /(\text { WACC }- \text { growth rate }) \\
=\text { LKR } 180 \mathrm{mn} /(0.18-0.12) \\
=\text { LKR 3,000 million }
\end{gathered}
$$

With the assumption of $12 \%$ future growth in EVA, MVA is 16.7 times of the current EVA, or (LKR $3,000 \mathrm{mn} / \mathrm{LKR} 180 \mathrm{mn}$ ). The fact that MVA is theoretically a multiple of the current EVA implies that any percentage change in EVA should cause the same percentage in MVA.

Several studies have been done by ample number of researchers by relating leverage and EVA with of MVA. Irala (2005) initiated a study on whether EVA possess a better explanatory power relative to the conventional accounting measures like earnings per share, return on net worth, capital productivity and labor productivity. The results supported that as compared to the other accounting measures, EVA has better explanatory power in predicting the market value.

The concept of shareholder value creation was examined by Kaur and Narang (2009) by using two value based metrics of financial performance namely EVA and MVA. For that study, 104 Indian firms have been used as sample and the findings reveal that EVA influences the market value of shares.

The correlation between EVA and MVA of 582 American companies was examined by Fernandez (2003) over 15 years from 1983 to 1997. The NOPAT had higher correlation with changes in MVA than the EVA for 296 firms in the sample whereas for 210 sample firms the correlation between EVA and MVA was found to be negative. In line with this, a study conducted on EVA-MVA relationship of 89 industrial firms in South Africa by De Wet (2005) found that EVA did not show the strongest association with MVA.

Pachari and Navindra (2012) conducted a study on the influence of financial leverage on shareholders' return and market capitalization of Automotive cluster companies in Pitahmpur. They found that there is no significant influence of financial leverage on shareholders' return and market capitalization.

It is clear from this brief review of literature that researchers have given much emphasize to EVA while gauging shareholder value creation. In the present scenario of corporate performance and management shareholders value creation aspect is of utmost importance. Therefore no one can repudiate the inevitability of an exclusive study in this area. By recognizing this necessity an attempt has been made to investigate the relationship between EVA, leverage and MVA.

\section{Research Methods}

\subsection{Mode of Analysis}

The findings of the research study were arrived at by using the quantitative research approach. Correlation analysis has been carried out to identify the cause-effect relationship between the predictor variables (EVA, Operating Leverage, Financial Leverage and Total Leverage) and dependent variable (MVA). Additionally, simple regression method has been used to find out the impact of leverage and EVA on MVA.

\subsection{Variables Used in the Study and the Creation of Research Model}

Table 1. Measurements of variables used in the analysis

\begin{tabular}{ll}
\hline Variables & Measurement \\
\hline Dependent variable & \\
Market Value Added (MVA) & Market Capitalization - Shareholders' Funds \\
\hline Independent variables & \\
Economic Value Added (EVA) & NOPAT - Cost of Capital Employed \\
Operational Leverage (OL) & Gross income/EBIT \\
Financial Leverage (FL) & EBIT/PBT \\
Total Leverage $(T L)$ & Financial Leverage x Operating Leverage \\
\hline
\end{tabular}

MVA has been used as the dependent variable whereas EVA, OL, FL and TL have been used as independent variables. In order to avoid multi collinearity and auto correlation issues, explanatory variables have been tested 
in four models rather than being tested in a single model. Based on the variables used in the study, the following regression models can be developed.

$$
\begin{array}{ll}
\text { MVA }=\beta_{0}+\beta_{1} X_{1}+\varepsilon \longrightarrow \text { Model I } \\
\text { MVA }=\beta_{0}+\beta_{1} X_{2}+\varepsilon \longrightarrow \text { Model II } \\
\text { MVA }=\beta_{0}+\beta_{1} X_{3}+\varepsilon \longrightarrow \text { Model III } \\
\text { MVA }=\beta_{0}+\beta_{1} X_{4}+\varepsilon \longrightarrow \text { Model IV }
\end{array}
$$

Where: $X_{1}=$ Economic Value Added; $X_{2}=$ Operating Leverage; $X_{3}=$ Financial Leverage; $X_{4}=$ Total Leverage; $\mathrm{MVA}=$ Market Value Added.

$\beta_{0}=$ Constant;

$\varepsilon=$ Error term.

\subsection{Conceptual Framework}

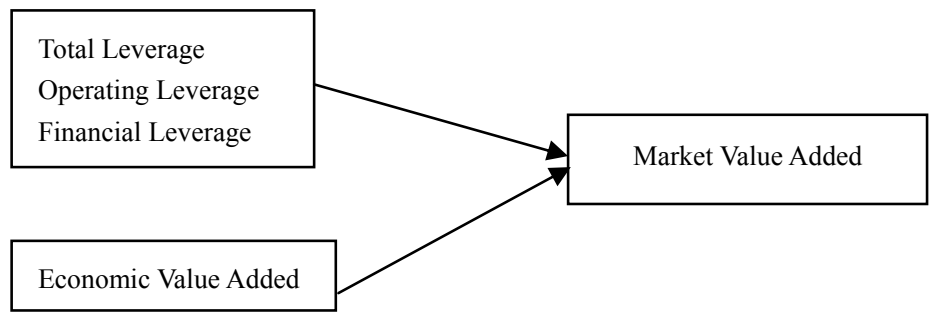

Figure 1. Conceptualization model

\subsection{Data Collection and Sampling Design}

The present study used secondary data for the analysis. As the key sources of data, financial statements consisting of balance sheets and income statements were used. Moreover, data were gathered via reference to the review of different articles, papers and relevant prior studies. Convenience sampling technique has been used to draw the sample from the Banks, Finance and Insurance sector. The sample of this study was confined to the 6 quoted private Sri Lankan banks representing the timeframe of 3 years from 2011 to 2013

\begin{tabular}{|c|c|c|c|c|c|c|}
\hline & & $E V A$ & $O L$ & $F L$ & $T L$ & MVA \\
\hline \multirow[t]{2}{*}{ EVA } & $\begin{array}{r}\text { Pearson correlation } \\
\text { Sig. }(2 \text { - tailed })\end{array}$ & 1 & & & & \\
\hline & $N$ & 6 & & & & \\
\hline \multirow[t]{3}{*}{$\overline{O L}$} & Pearson correlation & -0.428 & 1 & & & \\
\hline & Sig. (2 - tailed) & 0.635 & & & & \\
\hline & $N$ & 6 & 6 & & & \\
\hline \multirow[t]{3}{*}{$F L$} & Pearson correlation & -0.409 & $0.928 * *$ & 1 & & \\
\hline & Sig. (2 - tailed $)$ & 0.427 & 0.008 & & & \\
\hline & $N$ & 6 & 6 & 6 & & \\
\hline \multirow[t]{3}{*}{$T L$} & Pearson correlation & -0.407 & $0.951^{* *}$ & $0.992 * *$ & 1 & \\
\hline & Sig. (2 - tailed) & 0.423 & 0.004 & 0.000 & & \\
\hline & $N$ & 6 & 6 & 6 & 6 & \\
\hline \multirow[t]{3}{*}{$M V A$} & Pearson correlation & -0.275 & 0.006 & -0.205 & -0.172 & 1 \\
\hline & Sig. $(2-$ tailed $)$ & 0.598 & 0.991 & 0.697 & 0.744 & \\
\hline & $N$ & 6 & 6 & 6 & 6 & 6 \\
\hline
\end{tabular}

\section{Results and Analysis}

\subsection{Test of Relationship among the Variables Used in the Study}

Table 2. Correlation matrix

Note.**, Correlation is significant at the 0.01 level $(2$ - tailed).EVA= Economic Value Added; $\mathrm{OL}=$ Operating Leverage; $\mathrm{FL}=$ Financial Leverage; $\mathrm{TL}=$ Total Leverage; $\mathrm{MVA}=$ Market Value Added.

Table 2 exemplifies the existence of statistically insignificant relationship among the predictor variables (EVA, $\mathrm{OL}, \mathrm{FL}$ and TL) and MVA. Hence $\mathrm{H}_{1}$ and $\mathrm{H}_{2}$ both are rejected implies that there is no significant relationship 
between EVA and MVA and TL and MVA. The R value for the association between EVA and MVA was found to be negative and statistically insignificant. The findings of the correlation analysis are in line with the findings of the study conducted by the person named Fernandez (2003) by using a sample of 582 American companies over the period of 1983 to 1997 in order to test the cause-effect relationship between EVA and MVA. The association between EVA and MVA was found to be negative for 210 sample firms, the findings reveal.

\subsection{Regression Analysis}

Table 3. Results of the regression analysis

\begin{tabular}{lllll}
\hline Model & $\boldsymbol{R}$ & $\boldsymbol{R}^{2}$ & Adjusted R Square & Std. Error of the Estimate \\
\hline$I$ & 0.275 & 0.076 & -0.155 & 11526.91 \\
$I I$ & 0.006 & 0.000 & -0.250 & 11989.11 \\
$I I I$ & 0.205 & 0.042 & -0.198 & 11735.18 \\
$I V$ & 0.172 & 0.030 & -0.213 & 11810.50 \\
\hline
\end{tabular}

As you can see from the table 3 that $7.6 \%, 4.2 \%$ and $3 \%$ of the perceived variability in the models I, III and IV were demonstrated by the variations in the explanatory variables (EVA, FL and TL) used in the study. Remaining 92.4\%, 95.8\% and $97 \%$ of the variations in the models were associated with factors which were not shown in the models. These $\mathrm{R}^{2}$ values suggest that there might be factors which may have greater explanatory power in predicting MVA. Hence $\mathrm{H}_{3}$ and $\mathrm{H}_{4}$ both are rejected implying that EVA and leverage have no profound impact on MVA. Furthermore it is clear that Operating Leverage has no impact on MVA.

Table 4. Co-efficient for predictors of MVA

\begin{tabular}{llllll}
\hline \multirow{2}{*}{ Models } & \multicolumn{2}{l}{ Unstandardized co-efficients } & Standardized co-efficients & \multirow{2}{*}{ t-value } & \multirow{2}{*}{ Sig. } \\
\cline { 2 - 4 } & $\mathbf{B}$ & Std. Error & Beta & & \\
\hline Constant & 13547.18 & 7251.58 & & 1.868 & 0.135 \\
EVA & -0.478 & 0.836 & -0.275 & -0.572 & 0.598 \\
II & & & & \\
Constant & 9790.55 & 50412.88 & & 0.194 & 0.855 \\
OL & 418.66 & 35019.18 & 0.006 & 0.012 & 0.991 \\
III & & & & 0.367 \\
Constant & 17163.48 & 16879.03 & & -017 & 0.697 \\
FL & -1882.28 & 4497.87 & -0.205 & -0.418 & \\
IV & & & & 1.115 & 0.327 \\
Constant & 14665.54 & 13153.11 & & -0.349 & 0.744 \\
TL & -804.69 & 2303.41 & -0.172 & & \\
\hline
\end{tabular}

By referring to the table 4, the regression models can be written as follows;

$$
\begin{aligned}
& \text { MVA }=13,547.18-0.478 \mathrm{X}_{1}+\varepsilon \longrightarrow \text { Model I } \\
& \text { MVA }=9,790.55+418.66 \mathrm{X}_{2}+\varepsilon \longrightarrow \text { Model II } \\
& \text { MVA }=17,163.48-1,882.28 \mathrm{X}_{3}+\varepsilon \longrightarrow \text { Model III } \\
& \text { MVA }=14,665.54-804.69 \mathrm{X}_{4}+\varepsilon \longrightarrow \text { Model IV }
\end{aligned}
$$

As you can see from the models that EVA, FL, TL denoted by $\mathrm{X}_{1}, \mathrm{X}_{3}, \mathrm{X}_{4}$ respectively exhibit a negative association with MVA whereas OL denoted by $\mathrm{X}_{2}$ exhibits positive association with MVA. 


\subsection{Testing of Hypotheses}

Table 5. Hypotheses testing

\begin{tabular}{llll}
\hline No. & Hypotheses & Results & Tools \\
\hline$H_{1}$ & There is a significant relationship between EVA and MVA & Rejected & Correlation \\
$H_{2}$ & Total leverage exhibits a significant relationship with MVA & Rejected & Correlation \\
$H_{3}$ & There is a significant impact of EVA on MVA & Rejected & Regression \\
$H_{4}$ & Total leverage is having a significant impact on MVA & Rejected & Regression \\
\hline
\end{tabular}

\section{Discussion}

\subsection{Conclusion}

This study examined the association between EVA, leverage and MVA of the quoted private Sri Lankan banks. Data of 6 banks over the last 3 years from 2011 to 2013 has been used. Furthermore, Pearson correlation and simple regression methods have been employed in the analysis.

The $\mathrm{R}$ values were found to be weak and statistically insignificant for the association between EVA and MVA and leverage and MVA consisting the $R$ values of -0.275 and -0.172 respectively. Thus there is no clear evidence from the studies to support the claim that the shareholders stand to gain by looking at EVA. Moreover, leverage increases both the risk and reward of the investment. If the investment that is highly leveraged pans out and produces a profit. It will ultimately get reflected in the market value of shares and which in turn will increase MVA. However, if it fails decrease shareholders' wealth. Furthermore $R^{2}$ values reveal that the predictor variables used in the study have no explanatory power in predicting the changes in MVA. It is an indication that other factors are perhaps found to be better prognosticators of MVA.

\subsection{Limitations and Scope of Future Research}

One of the major limitations of the study is that the study is based on 3 years data. Only the listed private banks in Sri Lanka operating under the Banks, Finance and Insurance sector were selected as the sample for the study. Therefore one can extend the study to examine the industry wise relationship. Moreover, findings reveal that other factors are probably found to be better predictors of MVA rather than the explanatory variables used in the study. Hence, there is a gigantic space for more researches in this field.

\section{Acknowledgement}

We are very much obliged to thank the University Grants Commission of Sri Lanka for their immense support by way of funding the whole research. This support is very much appreciated for researchers like us to continue researches in their field of expertise.

\section{References}

Andries, A. M., \& Cocris, V. (2010). A comparative Analysis of the Efficiency of Romanaian Banks. Romanaian Journal of Economic Forecasting, 4, 54-75.

Casu, B., \& Girardone, C. (2004). Financial conglomeration: Efficiency, productivity and strategic drive. Applied Financial Economics, 14, 687-696.

Copeland, T. (2002). Want to create value? Strategic Finance, 83(9), 48-54.

De Wet, J. (2005). EVA versus traditional accounting measures of performance as drivers of shareholder value: a comparative analysis. Meditari Accountancy Research, 13(2), 1-16.

Ernst \& Young. (1994). EVA as a management tool, From “In Touch”. Reprinted in Accountancy SA.

Fernandez, P. (2003). EVA, economic profit and cash value added do not measure shareholder value creation. Journal of Applied Finance, 9(3), 74-94.

Fiordelisi, F. (2007). Shareholder Value and the Clash in Performance Measurement: Are Banks Special? University of Wales Bangor, Centre for Banking and Finance, U.K.

Gitman, L. J. (2000). Principles of Managerial Finance (9th ed.). Boston: Addison Wesley Longman.

Irala, L. R. (2005). Economic Value Added: The right measure of managerial performance. Indian Journal of Accounting and Finance, 119(2), 1-10.

Johnson, W. B., Natarajan, A., \& Rappaport, A. (1985). Shareholder Returns and Corporate Excellence. Journal 
of Business Strategy, 52-62.

Kaur, M., \& Narang, S. (2009). Insights on shareholder value addition from India's wealth club: A study of selected companies. The IUP Journal of Accounting Research \& Audit Practices, 8(3\&4), 20-51.

Misra, A., \& Kanwal, A. (2007). Economic value added as the most significant measure of financial performance: A study of selected Indian firms. Journal of Internal Business and Economics, 7(1), 76-85.

\section{Copyrights}

Copyright for this articleis retained by the author(s), with first publication rights granted to the journal.

This is an open-access article distributed under the terms and conditions of the CreativeCommons Attribution license (http://creativecommons.org/licenses/by/3.0/). 